INSIGHTS INTO REGIONAL DEVELOPMENT

ISSN 2669-0195 (online) http://jssidoi.org/IRD/

2019 Volume 1 Number 2 (June)

http://doi.org/10.9770/ird.2019.1.2(2)

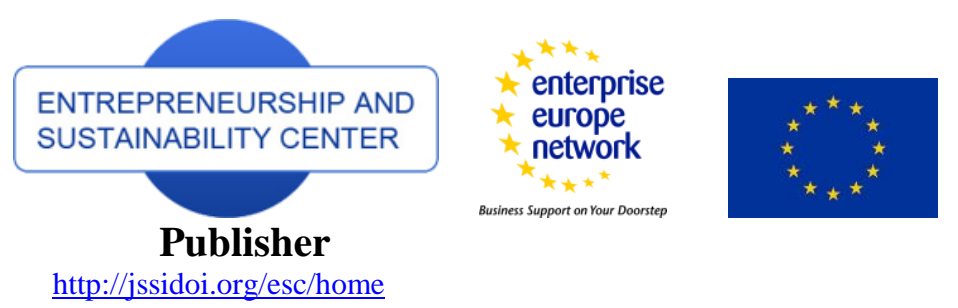

\title{
DOES THE WAGNER'S LAW EXIST IN A STRATEGIC NATIONAL AREA? AN EVIDENCE FROM KEDUNGSEPUR - INDONESIA*
}

\author{
Gatot Sasongko', Andrian Dolfriandra Huruta ${ }^{2}$, Anita Wardani ${ }^{3}$ \\ ${ }^{1,2,3}$ Satya Wacana Christian University, Faculty of Economics and Business, Diponegoro 52-60, Salatiga, Indonesia \\ E-mails: ${ }^{1}$ gatot.sasongko@staff.uksw.edu ; ${ }^{2}$ andrian.huruta@staff.uksw.edu (corresponding author); \\ 3222015044@student.uksw.edu
}

Received 6 April 2019; accepted 20 May 2019; published 30 June 2019

\begin{abstract}
The Kedungsepur National Strategic Area was formed to realize urban areas as the center of national and international economic activities. In order to realize this goal, government expenditure and economic growth are important variables in the development process. Empirically, the study was conducted to analyze the relationship between government expenditure and economic growth from the perspective of Wagner's Law in 6 regencies or cities in the Kedungsepur National Strategic Area during 2012 to 2017. Methodically, this study used Panel Granger Causality and Panel Data Regression to explain the short-term relationship between both variables. The results showed that there was a negative one-way relationship from economic growth to government expenditure. The increase in economic growth in the previous year would reduce the government expenditure in the short term, resulting the Wegner's Law inapplicable in the Kedungsepur National Strategic Area. This was due to the ineffectiveness of institutions, differences in regional expenditure structures towards state expenditures and the lack of government work programs in the productive sector. Thus, a good and coordinative institutional environment was needed to realize the cooperation in crucial sectors, as well as the distribution of regional expenditures on more productive expenditures based on priority interests, aiming at the welfare of the community.
\end{abstract}

Keywords: Wagner's Law, Economic Growth, Government Expenditure, Panel Granger Causality, Panel Data Regression

Reference to this paper should be made as follows: Sasongko, G.; Huruta, A.D.; Wardani, A. 2019. Does the Wagner's Law exist in a strategic national area? An evidence from Kedungsepur - Indonesia, Insights into Regional Development 1(2): 99117. https://doi.org/10.9770/ird.2019.1.2(2)

JEL Classifications: E6, R11, R58

\section{Introduction}

Since it was officially inaugurated in 2007 through Law Number 26 of 2007, the Kedungsepur National Strategic Area (Kendal, Demak, Ungaran, Salatiga, Semarang and Purwodadi) has become one of the most densely populated economic zones in Central Java and in the national level. The area covering Kendal Regency, Demak Regency, Semarang Regency, Salatiga City, Semarang City, and Grobogan Regency was formed to create urban areas as a center of international scale economic activities, based on trade and services, industry, tourism, without

\footnotetext{
* This research was supported by the project, which has received funding from the Satya Wacana Christian University under the 2018 internal competitive funding program for the scheme of university basic research.
} 
INSIGHTS INTO REGIONAL DEVELOPMENT

ISSN 2669-0195 (online) http://jssidoi.org/ird/

2019 Volume 1 Number 2 (June)

http://doi.org/10.9770/ird.2019.1.2(2)

overriding sustainable agricultural land (Presidential Regulation of the Republic of Indonesia, 2017). The map of the Kedungsepur National Strategic Area can be seen in Figure 1 below.

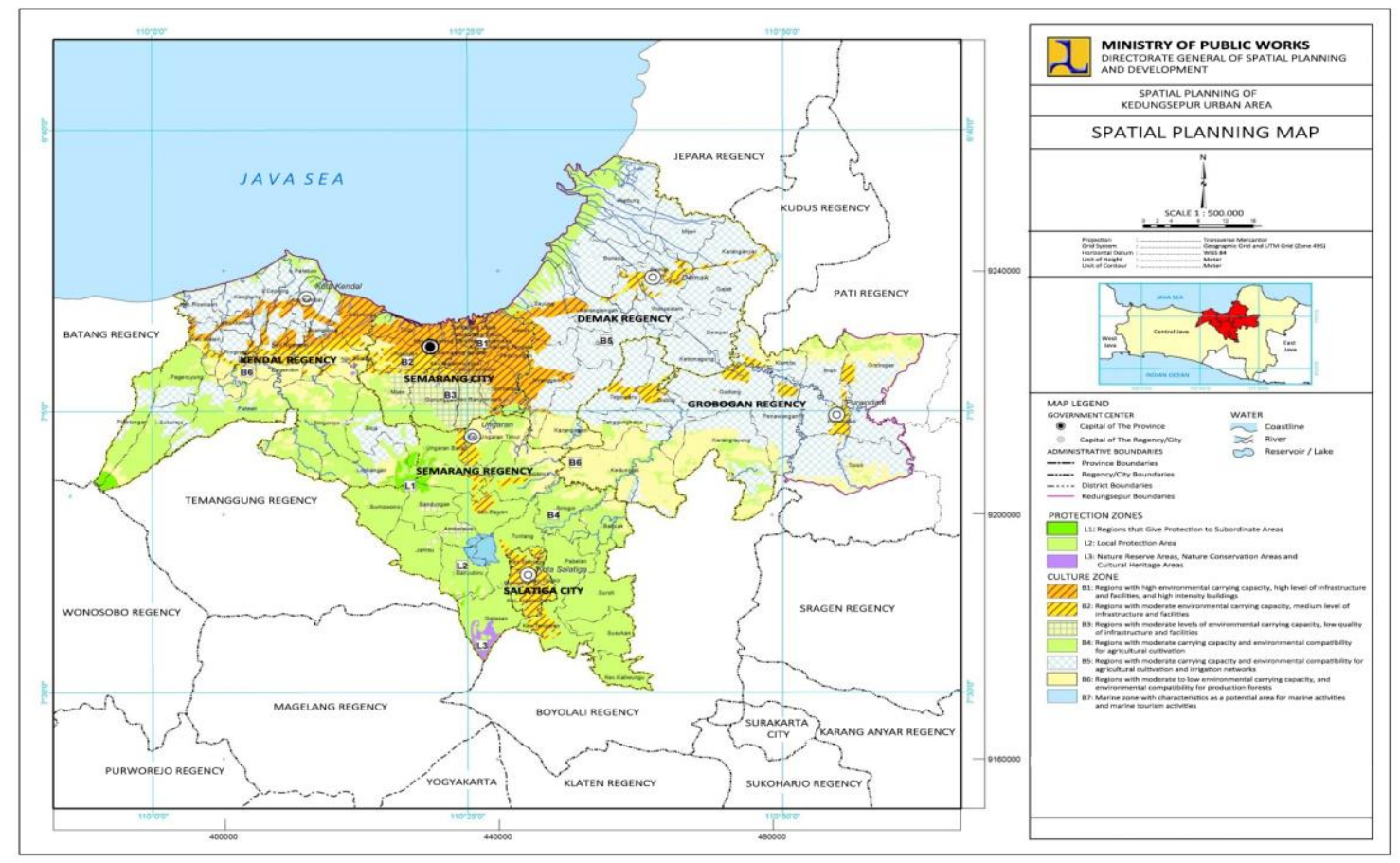

Fig. 1. Map of Kedungsepur National Strategic Area

Source: Ministry of Public Works (2014)

The government plays an important role in creating harmonization between regions through its policies and authorities. Government expenditures are distributed to increase regional productivity and improve communities' welfare. From 2012 to 2017, the government expenditure in the Kedungsepur Region tended to increase with an average growth rate of $14.14 \%$. In 2017, the total of the government expenditure in 6 regencies or cities in the Kedungsepur National Strategic Area reached Rp 12.974,16 billion or 5.79\% of the value of the Gross Regional Domestic Product (GRDP) of the Kedungsepur Region in 2017. Although it was inaugurated in 2007, the new Kedungsepur National Strategic Area Institution was formed in 2017 based on the Presidential Regulation of the Republic of Indonesia Number 78 of 2017. The absence of definite and poorly functioning existing authorities in coordinating the Kedungsepur National Strategic Area well had resulted in disparities between regions (Ministry of Public Works, 2014). This can be seen in Figure 2 below. 
INSIGHTS INTO REGIONAL DEVELOPMENT

ISSN 2669-0195 (online) http://jssidoi.org/ird/

2019 Volume 1 Number 2 (June)

http://doi.org/10.9770/ird.2019.1.2(2)

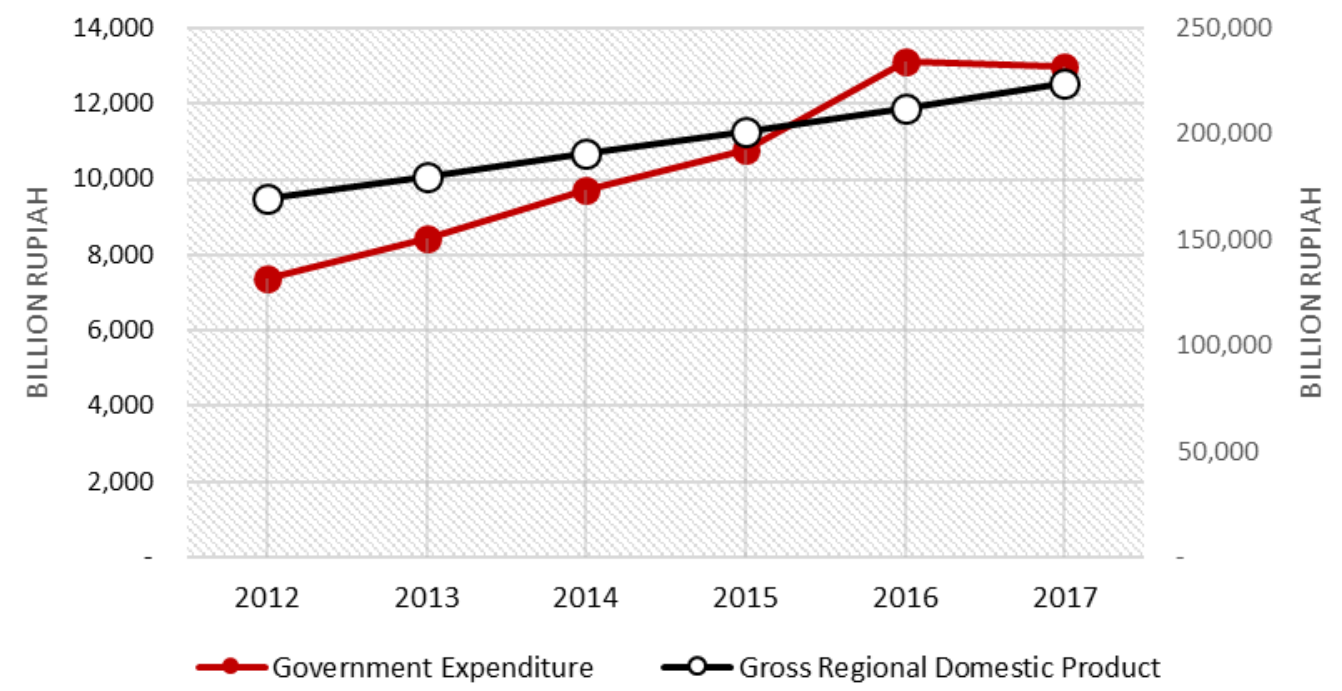

Fig. 2. Government Expenditure and Gross Regional Domestic Product at Constant Prices in Kedungsepur National Strategic Area 20122017

Source: Central Bureau of Statistics (2019)

Figure 2 explains the value of GRDP which tends to increase. The GRDP contribution for 6 regencies or cities in the Kedungsepur National Strategic Area in 2017 reaches $25.18 \%$ or more than a quarter of the GRDP value in Central Java Province. However, it was dominated by Semarang City with a percentage of $13.7 \%$. Whereas the contribution of GRDP to Demak Regency, Salatiga City and Grobogan Regency to the GRDP of Central Java in 2017 is still below the average, which is less than $2.86 \%$. As a special region with economic designation, the figure is certainly a problem. However, considering at the natural conditions and existing human resources, the Kedungsepur has sectors with a developing potential and it can encourage the economy of Central Java and the national level if appropriate policies are implemented.

The results of previous studies prove that an increase in the government expenditure was a result of an increased economic growth (Dada \& Adewale, 2013; García, 2018; Ismal, 2011; Magazzino, Giolli, \& Mele, 2015; Mohammadi \& Ram, 2015; Mutuku \& Kimani, 2012; Uzuner, Bekun, \& Akadiri, 2017; Wang, Peculea, \& Xu, 2016). On the other hand, previous researches were unable to prove the Wagner's Law, mentioning that when the economic growth got weakened, the government expenditure would increase (García, 2018). Furthermore, when the government expenditure increased, the economic growth would also increase (Ighodaro \& Oriakhi, 2010; Ismal, 2011; Kurniawati, 2018; Kyaw, 2018; Magazzino et al., 2015; Mohammadi \& Ram, 2015; Neduziak \& Correia, 2017; Okoro, 2013; Uddin \& Aziz, 2015). In addition, the relationship between the two variables showed a negative effect where there was an increase in the government expenditure, it would lower the economic growth (Hasnul, 2016; Manyeki \& Kotosz, 2017; Maurya \& Sigh, 2017; Ogundipe \& Oluwatobi, 2013).

The government expenditure and economic growth are two important variables in the development process. The relationship between these two has become such a debate in academic circles to date. The Wegnerian side considers that an increase in per capita income will encourage the expansion of the government to manage and regulate the market economy. In short, an increase in government expenditure adjusts for an increase in economic growth.

The government expenditure can be an endogenous factor which is a result of changes in economic growth and exogenous variables that can influence the level of economic growth. Keynes assumed that the government 


\section{INSIGHTS INTO REGIONAL DEVELOPMENT}

ISSN 2669-0195 (online) http://jssidoi.org/ird/

2019 Volume 1 Number 2 (June)

http://doi.org/10.9770/ird.2019.1.2(2)

intervention through an increase in the government expenditure could increase a country's output growth (Dillard, 1950; Skousen, 2006). Samuelson stated that an increase in per capita income would result in a decrease in the government expenditure (Dluhosch \& Zimmermann, 2006). The more increase the income, the more the private goods consumed compared to public goods, assuming the economy has developed with equitable infrastructure.

\section{Theoretical background}

The relationship between the government expenditure and economic growth is explained in Wagner's law. The government expenditure is endogenous towards the economic growth, where there is a long-term trend of increasing government expenditure as the economic growth increases. The Wagner's hypothesis on the relationship between the government expenditure and economic growth is interpreted into the following function equations (Hasnul, 2016):

$$
G E=f(Y)
$$

Equation 1 shows that GE is a public sector expenditure that reflects government expenditure, while $\mathrm{Y}$ is the national income, which in this case, is reflected in economic growth. There are 3 main reasons presented by Wagner on the relationship between the government expenditure and economic growth. First, the existence of industrialization and increasing economic growth are characterized by the dominance of the private sector as the economic actors. In this case, the government is needed to regulate the economy through law enforcement. Second, increasing per capita income will lead to increased public sector demand such as education, health, culture and other services. These needs are considered more efficient if they are managed by the government compared to a private management. Finally, the state invests in removing monopolistic tendencies in a country (Bird, 1971).

Literature discussing the relationship between the government expenditure and economic growth with the Wagner's legal direction has been widely practiced in various parts of the world. In Romania, Wang et al. (2016) who used Autoregressive Distributed Lag showed a positive one-way relationship from the government expenditure to economic growth. This indicated that the government could formulate a good economic policy strategy to deal with the precarious situation in the economy, such as during a crisis.

In general, the condition needed to support the Wagner's law is the existence of one-way causality in the economic growth to government expenditure. In Nigeria, Dada and Adewale (2013) used Vector Error Correction Model proved that there was a one-way causal relationship from the economic growth to government expenditure. The results also proved that the Wagner's law was a long-term phenomenon and not a short-term one. As per capita income increased, the public sector became increasingly important and required increased government expenditure.

Furthermore, Mutuku and Kimani (2012) who used a cointegration test and Granger causality found that the economic growth could increase the government expenditure. The amount of government expenditure was the result of decisions taken in the midst of changing economic conditions. However, it was highly important to organize and distribute these expenditures based on priority interests. Meanwhile, Uzuner et al. (2017) who used the Johansen co-integration test and Granger causality, tried to prove the Wagner's theory applied in Turkey. This finding indicated that the government expenditure would increase the output in the long run.

Another study was conducted by García (2018), who used a cointegration test with a structural breakpoint proved that the Wegner's Law was applied in Spain. However, the testing on the last 2 models showed a negative 


\section{INSIGHTS INTO REGIONAL DEVELOPMENT}

ISSN 2669-0195 (online) http://jssidoi.org/ird/

2019 Volume 1 Number 2 (June)

http://doi.org/10.9770/ird.2019.1.2(2)

relationship between the economic growth and government expenditure. This was due to the impact of the great recession in 2008 which required an implementation of a budget deficit policy by carrying out debt.

In Nigeria, Ighodaro and Oriakhi (2010) who used Granger causality proved that the Wagner's Law were not applicable. In other words, the government expenditure was such a variable that was able to drive the economic growth and with an increase in the government expenditure, it would not bring down the economy. When the government spent more money, it would encourage the economic growth, although the expenditure made was deficit (Kyaw, 2018; Neduziak \& Correia, 2017; Okoro, 2013; Uddin \& Aziz, 2015). The implementation of budget transfers in the right sectors can reduce budget distortion and also balance the government expenditure. In Myanmar, Kyaw (2018) who used cointegration tests stated that both variables were mutually integrated in the long run. While the results of the Granger causality test showed a positive and one-way relationship from the government expenditure to the economic growth. In line with Neduziak and Correia (2017) who used panel data found that the fiscal policy through the government expenditure was actually beneficial for the economic growth. Therefore, the fiscal organization is important for the sustainability of the economy.

In the same country, Okoro (2013) who used the Johansen cointegration test stated that there were long-term relationships in both variables. Although the economic growth in Nigeria during 1980-2011 tended to decline, an increase in the government expenditure would increase the value of the real GDP in the long run. Whereas in the short term, the growth would adjust the long-term balance at a rate of $60 \%$ per year. Allocating government expenditure in potential sectors (industry and agriculture) and infrastructure development would drive the economy. Similar to Uddin and Aziz (2015) who used Ordinary Least Squares proved that the government expenditure had a positive effect on the economic growth in Bangladesh. From the productive sector, the allocation for the construction of decent infrastructure could increase the economic activity. In addition to the economic conditions, the political stability in Bangladesh also showed that it had an important role in the economy.

In European countries, Magazzino et al. (2015) examined his study using Granger causality to prove that the Wagner's Law applied in 8 of 27 countries, namely: Bulgaria, France, Germany, Greece, Ireland, Portugal, Slovenia and Spain. The Wagner's Law was proven because as the output increased, the government intervention would be increasingly needed to manage the natural monopolies. Moreover, Mohammadi and Ram (2015) also proved that there was an existence of the Wagner's Law in Japan and Korea. However, it was not found in Malaysia, Philippines, Singapore and Thailand.

In Kenya, Manyeki and Kotosz (2017) used Autoregressive Distributed Lag stated that there was a resistance to the Wagner's Law. The results showed a negative and one-way relationship from the government expenditure to the economic growth. When the government expenditure increased, there would be a decline in the economic growth. This was due to the expenditure allocations that tended to be less productive and also due to poor institutions in Nigeria. This was in line with the findings of Ogundipe and Oluwatobi (2013) which stated that in addition to education and health expenditures, the amount of the government expenditure also negatively affected the economic growth in Nigeria in the period of 1970-2009. The results of the Johansen cointegration test made it clear that when the government increased its expenditure, the economic growth tended to decline. This happened because the government often allocated the expenditure on programs that could actually be covered by the private sector. The expenditure implementation at the regional level was often out of control. Therefore, there was a risk of fund misappropriation. Nevertheless, the government expenditure still played a role in stimulating the economic growth through capital expenditure.

In Malaysia, Hasnul (2016) who used Ordinary Least Squares and panel data also proved the existence of a negative relationship on the government expenditure and economic growth. The biggest influence was due to the housing sector and development spending. While the expenditures in the education, health, and operational 


\section{INSIGHTS INTO REGIONAL DEVELOPMENT}

ISSN 2669-0195 (online) http://jssidoi.org/ird/

2019 Volume 1 Number 2 (June)

http://doi.org/10.9770/ird.2019.1.2(2)

expenditure sectors did not show a significant effect. In the end, the management of allocation, supervision and sound institutions was such an important factor in a country's fiscal policy. The existence of a negative relationship caused by an increase in government expenditure might be a signal that the government expenditure did not lead to the economic growth.

In Indonesia, Ismal (2011) was able to prove that the government expenditure showed a positive performance towards the real sector. When the economic activities had good prospects, the government budget would also increase. This indicated that when the economic activity increased, the state revenues from the tax, export and import sectors would increase. It was assumed that an increase in income would lead to an increase in the budget. Furthermore, Kurniawati (2018) who used Granger causality proved a one-way relationship from the economic growth to the government expenditure in West Kalimantan. This happened as a result of the implementation of the regional autonomy since 2001 which authorized the local government to process the expenditure allocations according to priority. In other words, the right allocation to productive sectors would optimize the government expenditure and economic growth.

Overall, the previous studies conducted show various findings such as negative relationship, positive relationship, one-way causal relationship, absence of causal relationship and etc. This indicates that there is still an uncertain relationship between the government expenditure and economic growth (the Wagner's Law) in various countries.

\section{Methodology}

The data used in this study was secondary data obtained from the Indonesian Central Bureau of Statistics and websites of the regional government in the Kedungsepur National Strategic Area. Furthermore, the type of data used was panel data, consisting a combination of time series data and cross-section in 6 regencies or cities in the Kedungsepur National Strategic Area during 2012-2017. This period was chosen to get an overview of the economic conditions in the Kedungsepur National Strategic Area after it was inaugurated in 2007 through Law No. 26 of 2007. Theoretically, the Wagner's Law examines the relationship between the government expenditure and economic growth (Wang et al., 2016). The government expenditure is measured by the realization of the regional budget, while the economic growth is measured by the growth of GRDP at constant prices.

Panel data stationary was conducted to check whether the data had a variance that was not too large and a tendency to approach the average value. The panel data stationarity test was carried out using the Levin, Lin and Chu (LLC) test (Granger \& Newbold, 1974):

$$
Y_{i t}=\rho_{i} Y_{i t-1}+X_{i t} \delta_{i}+\epsilon_{i t}
$$

Equation 2 shows that $Y_{\text {it }}$ represents pooled variables, $X_{\text {it }}$ represents exogenous variables in the model, including fixed effects or individual trends, $\rho_{\mathrm{i}}$ is autoregressive coefficients, and errors ${ }_{\text {it }} \varepsilon_{i t}$ are assumed to be separate idiosyncratic disorders.

The Granger causality test is an empirical approach that is often used to prove differences in hypotheses in the Wagner's Law (Magazzino et al., 2015). Before carrying out the Granger causality test, it is necessary to determine the optimum lag. The determination of the optimum lag length aims to determine the length of the period of influence of a variable on endogenous variables with its past and other endogenous variables. To understand the length of the lag, the Akaike Information Criterion can be used, which are believed to be superior to other criteria (Winarno, 2015). The lower AIC value is able to decide the best lag length in the model (Gujarati \& Poter, 2009). 
After the best lag length was found, the Panel Granger causality test was performed by entering the optimal lag. The model describing the relationship between variables would be explained by the Panel Granger causality (Granger \& Newbold, 1974):

$$
\begin{aligned}
& Y_{i t}=\alpha_{0 i}+\alpha_{1 i} Y_{i t-1}+\ldots+\alpha_{k i} Y_{i t-k}+\beta_{1 i} X_{i t-1}+\ldots+\beta_{k i} X_{i t-k}+\epsilon_{i t} \\
& X_{i t}=\alpha_{0 i}+\alpha_{1 i} X_{i t-1}+\ldots+\alpha_{k i} X_{i t-k}+\beta_{1 i} Y_{i t-1}+\ldots+\beta_{k i} Y_{i t-k}+\epsilon_{i t}
\end{aligned}
$$

Equations 3 and 4 show that $X_{i t}$ is the amount of government expenditure in a given year and $Y_{i t}$ is the rate of economic growth in a given year, while $\varepsilon_{i t}$ is an error term assumed to contain no cross-correlation.

The approach used for Panel Granger causality testing in this study was a stacked test in which the panel data would be treated as a large set of data stacked without taking the left value of one cross-section to the next one. This method assumes that all coefficients are the same in all cross-sections with the following models (Granger \& Newbold, 1974):

$$
\begin{gathered}
\alpha_{0 i}=\alpha_{0 j}, \alpha_{1 i}=\alpha_{1 j}, \ldots, \alpha_{l i}=\alpha_{l j}, \forall_{i, j} \\
\beta_{1 i}=\beta_{1 j}, \ldots, \beta_{l i}=\beta_{l j} \forall_{i, j}
\end{gathered}
$$

The classic assumption test consists of multicollinearity, heteroscedasticity, autocorrelation, and normality testing (Winarno, 2015). However, in this study, only the heteroscedasticity test was needed. Multicollinearity testing phase was not done because this study only used one independent variable, resulting to the multicollinearity impossible to occur between the independent variables. Then, the autocorrelation testing was also not done because it generally occurs in time series data where the value of the sample or observation at a certain time point is influenced by the value of observation at a previous time (Gujarati \& Poter, 2009). However, in the panel data there is a repetition of time series data, resulting the autocorrelation test on panel data is considered to be meaningless. Furthermore, the normality testing was also considered meaningless because in the panel data, each object cross-section has a different average so that the residual average value also varies.

The heteroscedasticity test was done to test whether there was an inequality variance of residual of one observation to another which generally occurred in cross-section data. The heteroscedasticity test used the Glejser method by regressing all independent variables to the absolute value of the residual $|\mathrm{e}|$. If there is an effect of independent variables that are significant to the absolute value of the residuals, then there is a problem with heteroscedasticity in the model (Winarno, 2015). The equation for heteroscedasticity is as follows:

$$
|u|_{i}=\alpha+\beta X_{i}+v_{i}
$$

Equation 7 shows that an absolute residual value is an independent variable. In the panel data, random effect model uses the Generalized Least Squares method. While the fixed effect model and the common effect model use Ordinary Least Squares. Therefore, a heteroscedasticity test is needed so that the model can be used as a good predictor.

Based on the results of the Panel Granger causality test, panel regression tests were conducted to determine the relationship and how big the influence of economic growth rates and government expenditure in the 2012-2017 
Kedungsepur Region was. Models that can be applied in panel data regression are the common effect model, fixed effect model, and random effect models with the following equations (Winarno, 2015):

$$
\begin{gathered}
Y_{i t}=\alpha_{0}+\beta X_{i t}+e_{i t} \text { (common effect model) } \\
Y_{i t}=\alpha_{0 i}+\beta_{1} X_{i t}+\beta_{2} d_{l i}+\ldots+\beta_{7} d_{6 i}+e_{i t} \\
Y_{i t}=\alpha_{0 i}+\beta X_{i t}+e_{t} \quad \text { (fixed effect model) }
\end{gathered}
$$

Before conducting a panel data regression test, a verification of the appropriate model was needed. The process can be seen in Figure 3 below:

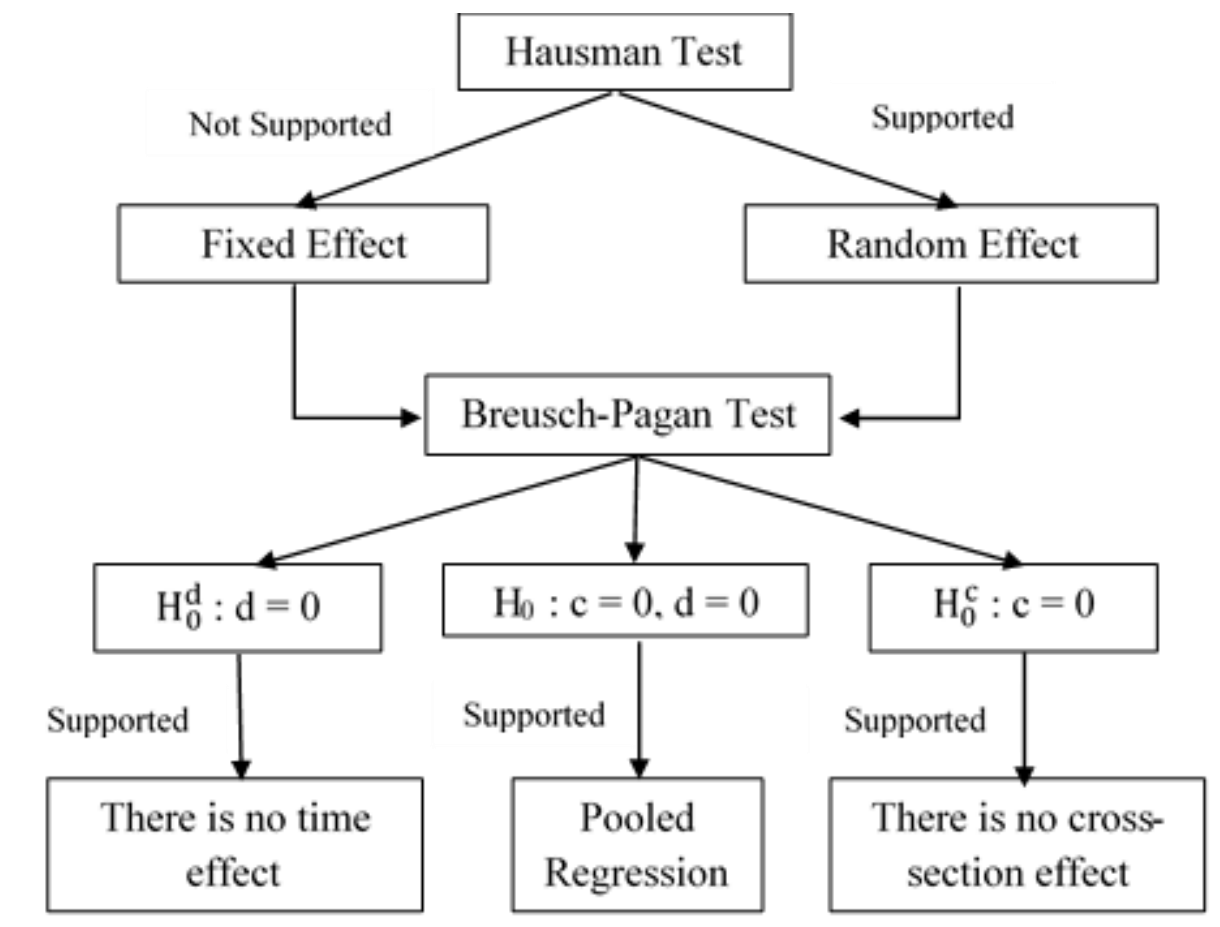

Fig. 3. Model Specification in Panel Data Regression Source: Rosadi (2012)

Figure 3 shows that the first stage is a Hausman test of data with the following hypothesis as follows:

$\mathrm{H}_{0}: \mathrm{E}\left(\mathrm{C}_{\mathrm{i}} \mid \mathrm{X}\right)=\mathrm{E}(\mathrm{u})=0$, there is a random effect in the model

$H_{a}: E\left(C_{i} \mid X\right)=E(u) \neq 0$, there is no random effect in the model

If the probability value is smaller than the level of significance $(\alpha=5 \%)$, then H0 is rejected. Thus, the best model used is the fixed effect model. Conversely, if the ignition value is greater than the level of significance $(\alpha=5 \%)$, then $\mathrm{H} 0$ is accepted. Thus, the best model to be used is the random effect model. 
Next, a Breusch-Pagan test was carried out to understand if there was a cross-section or time (or both) effect in the panel data by testing the hypothesis (Rosadi, 2012):

$\mathrm{H}_{\mathrm{o}}: \mathrm{c}=0, \mathrm{~d}=0$, there is no effect on cross-section or time

$\mathrm{H}_{0}^{\mathrm{c}} \mathrm{H}_{0}^{\mathrm{c}}: \mathrm{c}=0$, there is no effect on cross-section

$\mathrm{H}_{0}^{\mathrm{d}} \mathrm{H}_{0}^{\mathrm{d}}: \mathrm{d}=0$, there is no effect on time

$\mathrm{H} 0$ is accepted if the probability value is greater than the level of significance ( $\alpha=5 \%$ ). If the Breusch-Pagan test hypothesis is accepted, an analysis is performed using a panel data regression model.

\section{Results}

The unit root test results are carried out by entering individual trends and analyzed based on the Levin, Lin \& Chu (LLC) tests on the panel data. The unit root test results can be seen in Table 1 below.

Table 1. Panel Data Stationary Test

\begin{tabular}{|c|c|c|c|}
\hline Variable & Degree of Integration & $\begin{array}{c}\text { Prob. } \\
\text { LLC }\end{array}$ & Conclusion \\
\hline DGrowth & First difference & 0.0000 & panel has stationary \\
\hline DGoverment & First difference & 0.0000 & panel has stationary \\
\hline
\end{tabular}

Source: Research findings

Table 1 indicates that the economic growth has been stationary in the degree of integration of the first difference. This is indicated by a probability value that is smaller than the level of significance $(\alpha=5 \%)$. The same case also happens to the government expenditure variables that are stationary on the degree of integration of the first difference. This is indicated by a probability value that is smaller than the level of significance $(\alpha=5 \%)$.

The optimal determination of lag using the lag length test was carried out before carrying out the Granger causality testing. The results of the lag length test can be seen in Table 2 below.

Table 2. Lag Length Test

\begin{tabular}{|c|c|c|c|c|c|c|}
\hline Lag & LogL & LR & FPE & AIC & SC & HQ \\
\hline 0 & -176.7912 & NA & $3.00 \mathrm{e}+10$ & 29.79853 & 29.87935 & 29.76861 \\
\hline 1 & -163.3297 & $20.19228^{*}$ & $6.32 \mathrm{e}+09^{*}$ & $28.22161^{*}$ & $28.46407 *$ & 28.13185 \\
\hline 2 & -159.2020 & 4.815609 & $6.75 \mathrm{e}+09$ & 28.23034 & 28.60442 & 28.05073 \\
\hline 3 & -155.2420 & 3.300036 & $8.54 \mathrm{e}+09$ & 28.23699 & 28.77272 & $27.99754 *$ \\
\hline
\end{tabular}

Source: Research findings

*indicates the optimal lag

Table 2 shows that the most optimal lag is lag 1. This can be seen in the Akaike value that the smallest information criterion is 28.22161. Thus, lag 1 was used for Panel Granger causality testing between the economic growth and government expenditure.

The Panel Granger causality test was conducted to determine whether the Wagner's Law was proven. The results of the Panel Granger causality test using the Stacked Test causality can be seen in Table 3 below. 
INSIGHTS INTO REGIONAL DEVELOPMENT

ISSN 2669-0195 (online) http://jssidoi.org/ird/

2019 Volume 1 Number 2 (June)

http://doi.org/10.9770/ird.2019.1.2(2)

Table 3. Panel Granger Causality Test

\begin{tabular}{|c|c|c|}
\hline Null Hypothesis & F-Statistic & Prob. \\
\hline DGovernment does not Granger Cause DGrowth & 0.03798 & 0.8474 \\
\hline DGrowth does not Granger Cause DGovernment & 4.74360 & 0.0410 \\
\hline
\end{tabular}

Source: Research findings

Table 3 shows that the hypothesis, stating that there is no Granger causality between the economic growth and the government expenditure, is not accepted. The $\mathrm{H}_{0}$ rejection is based on a probability value of 0.0410 which is smaller than the level of significance $(\alpha=5 \%)$. While the hypothesis, stating that there is no Granger causality between the government expenditure and economic growth, is accepted. The $\mathrm{H}_{0}$ acceptance is based on a probability value of 0.8474 which is greater than the level of significance $(\alpha=5 \%)$.

Thus, it could be concluded that there had been a one-way relationship from the economic growth to the government expenditure. This revealed that changes in economic growth caused changes in the government expenditure, but not vice versa. This also indicated that the possibility of the Wagner's Law was applied in the Kedungsepur Region. However, the panel data regression testing was needed to determine the direction of the relationship and ensure the existence of the Wagner's Law in the Kedungsepur National Strategic Area.

The Hausman test was the first step before panel data regression was carried out. This aimed to see if there was a random effect on the panel data. The test results can be seen in Table 4 below.

Table 4. Hausman Test

\begin{tabular}{|l|c|c|}
\hline & Prob. & The Best Estimation Model \\
\hline Hausman Test & 0.6823 & Random Effect Model \\
\hline
\end{tabular}

Source: Research findings

Table 4 shows that the probability value in the Hausman test is greater than the level of significance $(\alpha=5 \%)$. This indicates that the hypothesis $\mathrm{H}_{0}$ is accepted or there is a random effect in the model. Therefore, the most appropriate model to explain the phenomenon of short-term relationships between the economic growth and government expenditure was the random effect model. Thus, the best model used in the panel data regression was the random effect model.

Next, the Breusch-Pagan test was performed to see whether there was any effect on time or cross-section in the data. The summary for the Breusch-Pagan test can be seen in Table 5 below.

Table 5. Breusch - Pagan Test

\begin{tabular}{|l|c|c|}
\hline \multicolumn{1}{|c|}{ Hypothesis } & Prob. & Conclusion \\
\hline Cross-section & 0.1412 & $\mathrm{H}_{0}$ is accepted \\
\hline Time & 0.3218 & $\mathrm{H}_{0}$ is accepted \\
\hline Both & 0.0761 & $\mathrm{H}_{0}$ accepted \\
\hline
\end{tabular}

Table 5 shows that there is no effect of cross-section or time on the model. This is indicated by the hypothetical cross-section value of 0.1412 which is greater than the level of significance $(\alpha=5 \%)$, the probability of time of 0.3218 which is greater than the level of significance $(\alpha=5 \%)$ and the hypothetical cross-section and time series of 0.0761 which is greater than the level of significance $(\alpha=5 \%)$. Thus, the three Breusch - Pagan test results accept the $\mathrm{H}_{0}$ or in short, there are no cross-section or time effects. 
Before conducting the panel data regression analysis, it is necessary to do a classic assumption test. In this case, the classic assumption test carried out was only the heteroscedasticity test to understand whether there is an inequality of variation from the residual of one observation to another. The summary of the heteroscedasticity test results can be seen in Table 6 below.

Table 6. Heteroscedasticity Test

\begin{tabular}{|rr|c|}
\hline Dependent Variable: RESABS & \multicolumn{2}{|c|}{ Prob. } \\
\hline Variable & 0.8064 \\
\hline DGrowth & Source: Research findings & \\
\hline
\end{tabular}

Table 6 shows that data is not subjected to heteroscedasticity. This is evidenced by the probability value of the independent variable where the economic growth greater than the level of significance $(\alpha=5 \%)$. Thus, $\mathrm{H}_{0}$ is accepted and the variance of the residuals between observations is the same.

After conducting the heteroscedasticity test, the final step was to do a panel data regression test. The panel data regression test results with random effect models can be seen in Table 7.

Table 7. Panel Data Regression Test

\begin{tabular}{|l|c|c|c|}
\hline \multicolumn{1}{|c|}{ Variable } & Coefficient & t-Statistic & Prob. \\
\hline C & 189234.2 & 3.019967 & 0.0053 \\
\hline DGrowth & -120207.8 & -2.499745 & 0.0186 \\
\hline R-Squared & 0.186997 & & \\
\hline Prob (F-statistic) & 0.017006 & & \\
\hline
\end{tabular}

Table 7 shows that the economic growth has a negative and significant effect on the government expenditure in the Kedungsepur National Strategic Area. This can be seen from the probability value of THE economic growth which is smaller than the level of significance $(\alpha=5 \%)$. This proves that the Wagner's Law did not apply in the Kedungsepur Region.

\section{Discussion}

National strategic areas in an economic interest perspective were formed because they were considered capable of having an important influence on the national economy. According to the (Ministry of Public Works, 2014), the region must meet the criteria of regions with economic growth potential, had a superior sector, the potential for exports, economic activities with high-tech devices, a network of infrastructure supporting economic activities, potential food and energy security, and were able to accelerate equity.

Since its inauguration in 2007, the Kedungsepur National Strategic Area had experienced dramatic growth. The population increased by $5.83 \%$ during 2012-2017 accompanied by economic transformation. The increase triggered an increase in economic activity in the Kedungsepur National Strategic Area which could also be seen from the increase in the value of GDP at a constant price of 2010. However, the economic growth in 2012 to 2017 had a trend that tended to slow down despite its growth accompanied by an increase in per capita income. This can be seen in Figure 4 below. 
INSIGHTS INTO REGIONAL DEVELOPMENT

ISSN 2669-0195 (online) http://jssidoi.org/ird/

2019 Volume 1 Number 2 (June)

http://doi.org/10.9770/ird.2019.1.2(2)

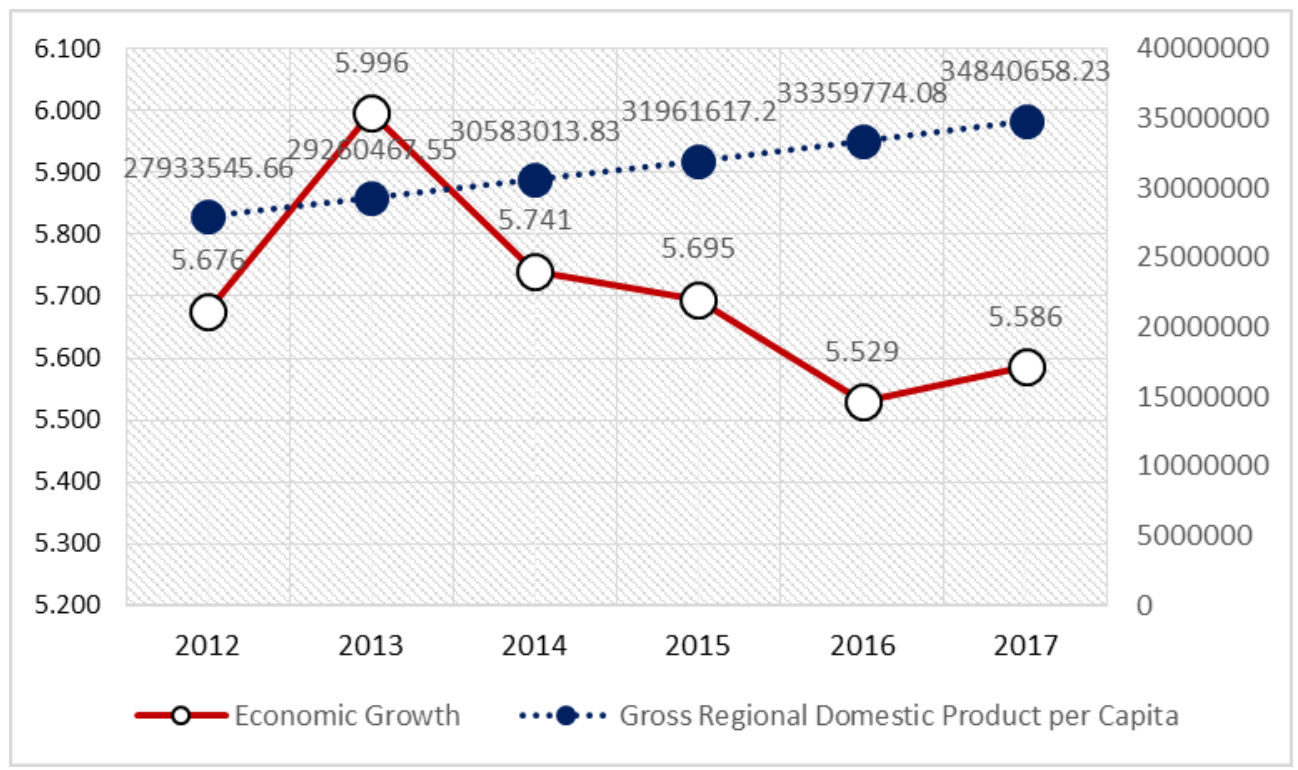

Fig. 4. Economic Growth of the Kedungsepur National Strategic Area 2012-2017

Source: Central Bureau of Statistics (2019b)

Based on Figure 4, the highest economic growth in the Kedungsepur National Strategic Area in 2013 reaches a percentage of 5.996\%. In 2013, the economic growth of Kendal Regency, Salatiga City and Semarang City reaches the highest growth rate for 6 years, which is more than 6\%. However, in 2014 to 2016, the economic growth of the Kedungsepur National Strategic Area slows to reach its lowest point in 2016 of 5.529\%. Nonetheless, the per capita GRDP shows an increasing trend. During 2012 to 2017, the increase in per capita income is $4.518 \%$. The value of the Kedungsepur's per capita income in 2017 is IDR 34.840 .568 per year with the highest per capita income by the City of Semarang at IDR 69.409.690 per year and the lowest by Grobogan Regency at IDR 12.904.456 per year.

The Kedungsepur National Strategic Area covered 4 Regencies and 2 Cities with dense economic activities. In this regard, the role of the government was needed to develop infrastructure and facilities to support the economic activities (Ministry of Public Works, 2014). From 2012 to 2017, the government expenditure in the Kedungsepur National Strategic Area tends to increase with an average growth rate of $14.14 \%$. The government expenditure was divided into several parts. To get an overview of the government expenditure of the Kedungsepur National Strategic Area, it can be seen in Figure 5 below. 


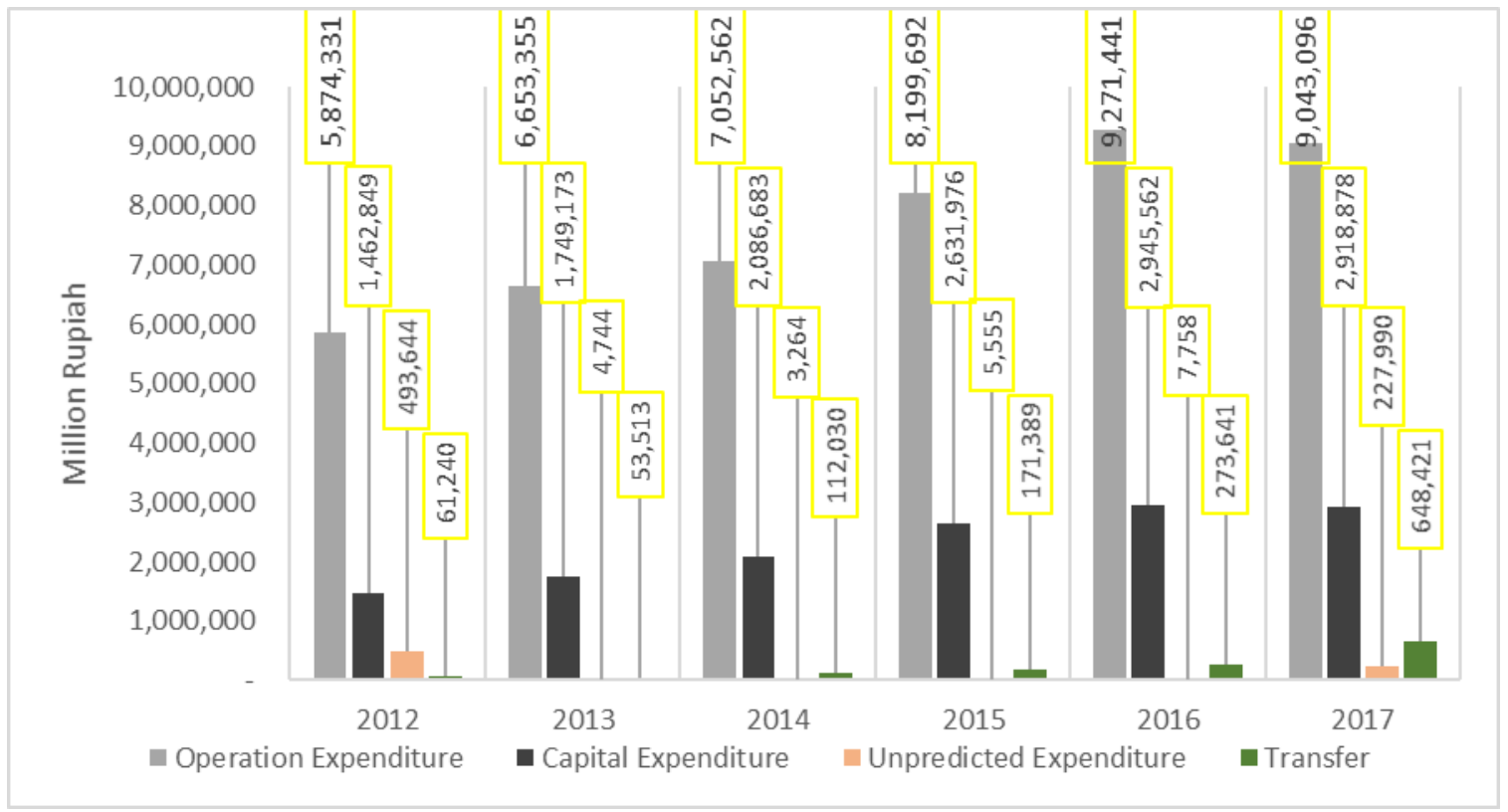

Fig. 5. The Realization of Regional Expenditures by Types of Expenditures in Kedungsepur National Strategic Area 2012-2017 Source: Central Bureau of Statistics (2019a)

Figure 5 shows that the operating expenditure dominates the local government expenditure each year. In 2012, the operating expenditures reaches $\mathrm{Rp} 5.874,33$ billion, with a proportion of $74.4 \%$ of the total expenditure in the regency or city of the Kedungsepur National Strategic Area. It reaches its peak in 2016 of Rp 9.271,44 billion. While the average capital expenditure per year is $\mathrm{Rp} 2.299,19$ during 2012-2017. The lowest proportion of regional expenditure is unexpected expenditure and transfers with a value of less than $\mathrm{Rp} \mathrm{700,00} \mathrm{billion.} \mathrm{The}$ Kedungsepur National Strategic Area consists of 6 regions with different economic sizes. The denser the economy, the higher the budget needed (Adisasmita, 2011). This can be seen in Figure 6 below.

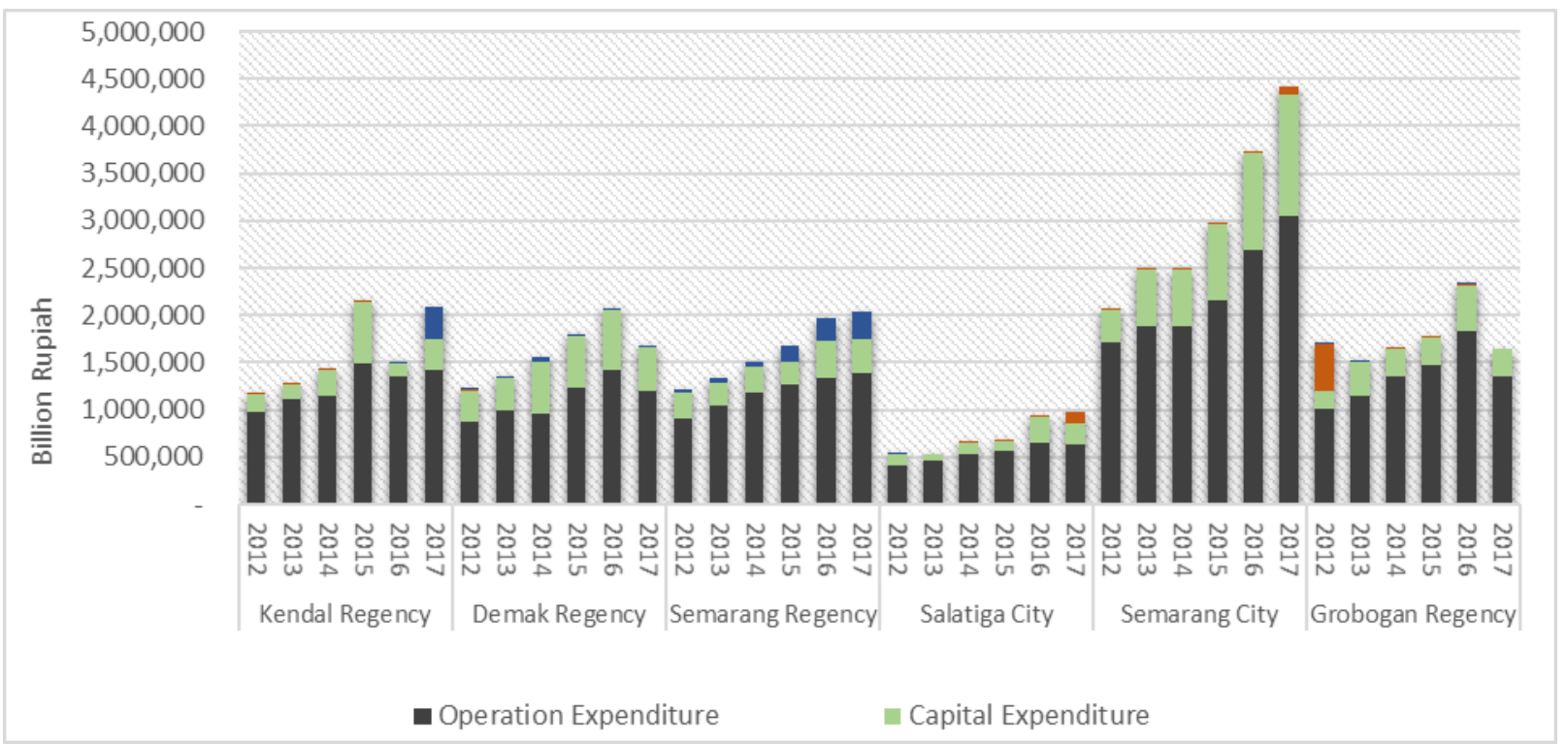

Fig. 6. The Realization of the Regional Expenditures by Type of Expenditures in Kedungsepur National Strategic Area 2012-2017 Source: Central Bureau of Statistics (2019a) 
INSIGHTS INTO REGIONAL DEVELOPMENT

ISSN 2669-0195 (online) http://jssidoi.org/ird/

2019 Volume 1 Number 2 (June)

http://doi.org/10.9770/ird.2019.1.2(2)

Figure 6 shows that the government expenditure in each region tends to be different. The highest expenditure is by the Semarang City in 2017 with a value of Rp 4.424,77 billion. Besides being the capital city of Central Java, Semarang City is the most populous region with a population of 1.027 .489 inhabitants. While the lowest government expenditure is by Salatiga City of Rp 529,22 billion in 2013. The regional expenditure was also based on the population and the needs of the region itself. Regions with fewer residents tended to have a small proportion of expenditure, while regions with high population levels and high population densities tended to have higher government expenditure.

This study aims to analyze the relationship between the government expenditure and the economic growth. More specifically, this study is focused on testing whether the Wagner hypothesis is proven in regencies or cities in the Kedungsepur National Strategic Area during 2012-2017. The Granger causality test results show that there is a one-way relationship from the economic growth to the government expenditure. The government expenditure was an endogenous factor that would change along with changes in the economic growth. Then, the result of the panel regression test with a random effect model proved that the economic growth has a negative and significant effect on the government expenditure in the Kedungsepur National Strategic Area. These results confirm that the Wagner's Law did not apply in the Kedungsepur Region in the short term. This condition is consistent with the findings of García (2018) who found a negative relationship between the economic growth and the government expenditure. This finding is also in line with the Samuelson's argument that when per capita income increased, the expenditure in the public sector would decrease (Dluhosch \& Zimmermann, 2006). However, the fact in the Kedungsepur Area was unable to support the reasons conveyed by Samuelson that if the income per capita increased, the people would get richer and tended to prefer to consume private goods rather than public goods. Whereas during 2012-2017, the value of per capita GRDP in the Kedungsepur National Strategic Area, especially in Grobogan Regency and Demak Regency, was below the Central Java per capita GRDP (Central Bureau of Statistics, 2019b).

There were several factors making it possible to cause a negative relationship between the government expenditure and the economic growth in Kedungsepur. First, Wagner considers that with increasing economic growth and increasingly complex economic activities, the government expenditure is needed to create rules to enforce the law (Bird, 1971; Dluhosch \& Zimmermann, 2006; García, 2018; Ighodaro \& Oriakhi, 2010; Kurniawati, 2018; Wang et al., 2016). In fact, the Kedungsepur institutional condition did not function well before the enactment of Presidential Regulation of the Republic Indonesia Number 78 (Presidential Regulation of the Republic of Indonesia, 2017). This results in a weak coordination between sectors and regions in the Kedungsepur region. Although it has been inaugurated since 2007 with the label of the National Strategic Area, overly passive relationships made the Kedungsepur area as if it was only an area adjacent to each other. Interactions that had been built for more than 10 years were only limited to coordination with very minimal program implementation. In addition, there had been no financial support from the State Budget to operate both in terms of planning or realization of burdening the Local Government Budget of the regencies or cities in the Kedungsepur region (Ministry of Public Works, 2014). The local governments tended to focus more on the development of their respective regions without understanding the purpose of the establishment of the Kedungsepur National Strategic Area, resulting to a lack of cooperation between regions that made it had no regulations needed to be created. Therefore, although the economic growth had increased, the government expenditure on making regulations had not increased and even decreased. Second, Wagner considers that when per capita income increases, it will also increase public sector demand such as education, health, culture, and other services (Bird, 1971; Dada \& Adewale, 2013; Dluhosch \& Zimmermann, 2006; Kurniawati, 2018; Ogundipe \& Oluwatobi, 2013). It should reemphasized that the regional expenditure structure differred from the national or central expenditure structure (Kurniawati, 2018). The Local Government Budget was focused on the development, regional accessibility, improving the quality of public services, and community welfare with a $25 \%$ budget for infrastructure expenditure (Directorate General of Budget, 2019). While the budget for public welfare such as the education, health, 
infrastructure, social protection, and subsidy budgets was partly financed through the State Budget. This is what caused the proportion of regional expenditure to focus more on unproductive activities. This can be seen Figure 7 below.

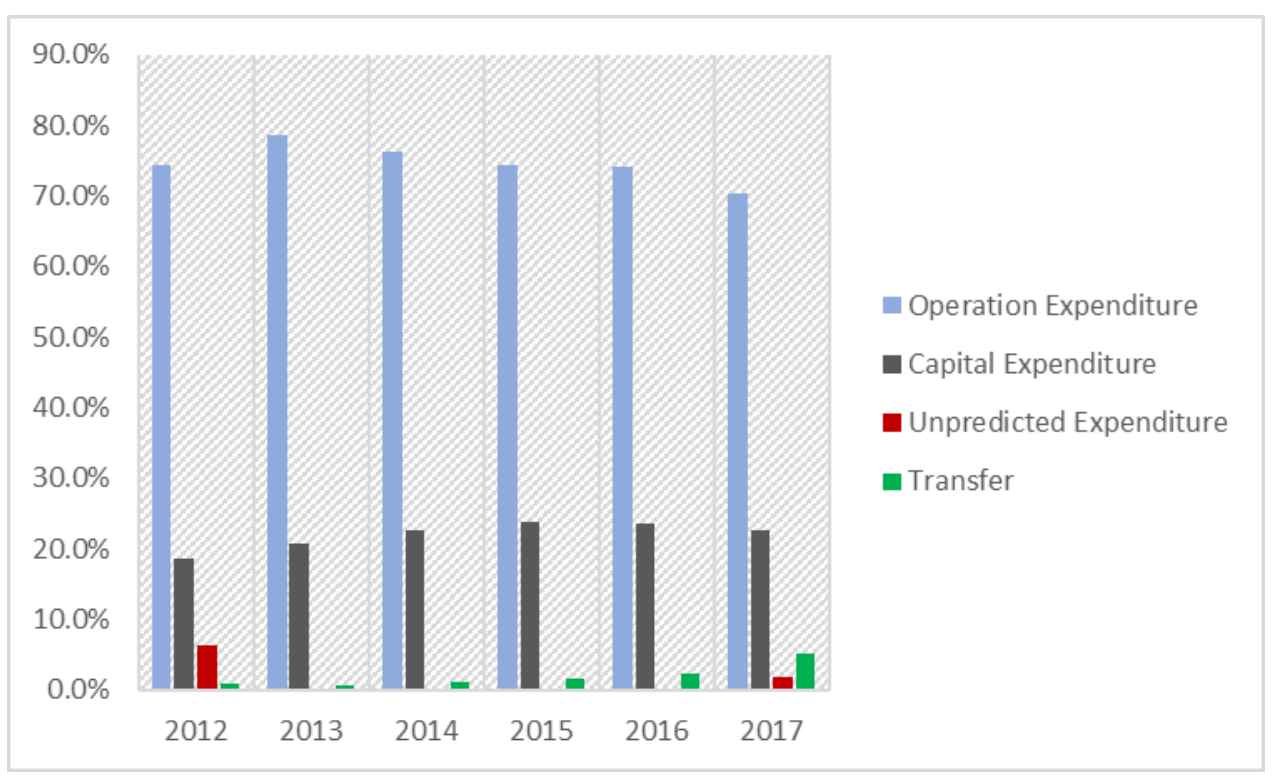

Fig. 7. Budget Structure in Kedungsepur National Strategic Area 2012-2017 Source: Central Bureau of Statistics (2019a)

Figure 7 shows the government expenditure structure of the Kedungsepur National Strategic Area dominated by operation expenditure with personnel expenditure as the sector that contributed the largest expenditure with an average value of $41.56 \%$ during 2012-2017. While the expenditure on subsidies, grants, social assistance, and financial assistance for 6 years only contributed an average of less than 3\%. Compared to being allocated to the productive sector or directly benefiting the people, the regional budget in the Kedungsepur National Strategic Area is dominated by administrative expenditure. In addition, the capital expenditure by regencies or cities in the Kedungsepur National Strategic Area is an average of $21.99 \%$ per year. This resulted in regional government expenditure not reacting optimally to increasing economic growth in the Kedungsepur National Strategic Area, making the effect negative. Third, Wagner believes that if the economy advances, government investment is needed to eliminate monopolistic tendencies by the private sector in a country (Bird, 1971; Dluhosch \& Zimmermann, 2006). Thus, the expenditure is allocated as much as possible to productive sectors (Hasnul, 2016; Manyeki \& Kotosz, 2017; Mutuku \& Kimani, 2012; Neduziak \& Correia, 2017). However, outside of individual regional projects, the cooperation projects realized in the Kedungsepur National Strategic Area were still very few. Until this moment, the programs that had been running include Indonesian Railroad of Kedungsepur, Trans Central Java Bus, and public transportation routes. In fact, several fields of cooperation needed to be immediately carried out such as transportation, drinking water, solid waste, tourism, environmental treatment, and food security, where if the government did not intervene quickly, it could create a monopoly by the private sector. The lack of cooperation programs was not able to increase the government expenditure although the economic growth in each of the Kedungsepur regions had increased. 
INSIGHTS INTO REGIONAL DEVELOPMENT

ISSN 2669-0195 (online) http://jssidoi.org/ird/

2019 Volume 1 Number 2 (June)

http://doi.org/10.9770/ird.2019.1.2(2)

\section{Conclusions}

This study proves that the Wegner's Law did not apply in the Kedungsepur National Strategic Area in the short term from 2012 to 2017. The results of the Granger causality test show that there was a unidirectional relationship in which the economic growth caused government expenditure. The government expenditure was such an endogenous factor that will change with changing economic growth. However, based on the panel regression test, it shows that economic growth had a significant negative effect on the government expenditure in the Kedungsepur National Strategic Area. The increase in economic growth in the previous year would reduce the government expenditure in the short term. There were several factors causing an absence of the Wagner's Law in the Kedungsepur National Strategic Area including (1) no institutional establishment in the Kedungsepur National Strategic Area which resulted in a weak coordination between sectors and regions. In addition, there was no financial support from the State Budget for operations, both in terms of planning or realization of the program, which finally weighing down the Local Government Budget in the Kedungsepur National Strategic Area; (2) differences in the structure of regional budgets with the structure of state budgets made the proportion of regional expenditure leaning on unproductive activities. This resulted in local government expenditure not reacting optimally to increasing growth; and (3) the lack of cooperation programs between regions made the regional government expenditure unproductive.

Basically, the government expenditure is an important factor to drive the economy. An effective institutional environment needs to be established to create strong relations between the Kedungsepur National Strategic Area. Existing institutions must be able to carry out intensive coordination to realize the cooperation in crucial sectors. The distribution of regional expenditure must be realized based on the priorities of the interests and welfare of the community. Furthermore, to increase the government's role in the Kedungsepur National Strategic Area, a cooperation needs to be carried out immediately in several fields such as transportation, drinking water, solid waste, tourism, environmental treatment, and food security which if the government does not intervene quickly, it can create a monopoly by the private sector. Furthermore, as this research is based on theory proving, further research is suggested to use the Structural Vector Autoregression (SVAR) model in a wider range of regions.

\section{Aknowledgements}

This research wassupported by the project, which has received funding from the Satya Wacana Christian University under the 2018 internal competitive funding program for the scheme of university basic research.

\section{References}

Bird, R. M. (1971). Wagner's Law of Expanding State Activity. Public Finance, 26(1), 1-26. Retrieved from https://www.researchgate.net/publication/226647729_Wagner's_Law_of_Expanding_State_Activity

Central Bureau of Statistics. (2019a). Data Pertumbuhan ekonomi, Pengeluaran Pemerintah, dan PDRB Kedungsepur. Retrieved from https://jateng.bps.go.id/

Central Bureau of Statistics. (2019b). Laju Pertumbuhan PDB/PDRB. Retrieved from https://sirusa.bps.go.id/index.php?r=indikator/view\&id=3

Dada, M. A., \& Adewale, O. A. (2013). Is Wagner's Law A Myth or Reality? Empirical Evidence from Nigeria. International Journal of Development and Economic Sustainability, $1(1), \quad 123-137 . \quad$ Retrieved 
INSIGHTS INTO REGIONAL DEVELOPMENT

ISSN 2669-0195 (online) http://jssidoi.org/ird/

2019 Volume 1 Number 2 (June)

http://doi.org/10.9770/ird.2019.1.2(2)

https://www.google.com/url?sa=t\&rct=j\&q=\&esrc=s\&source=web\&cd=2\&ved=2ahUKEwidqMe4vorhAhWIu48KHZppBGMQFjABegQI BBAC\&url=http\%3A\%2F\%2Fwww.eajournals.org\%2Fwp-content\%2Fuploads\%2FIs-Wagner\%25E2\%2580\%2599s-Law-a-Myth-or-aReality-Empirical-Evidence-from-Nigeri

Dillard, D. (1950). The Economics of John Maynard Keynes, The Theory of a Monetary Economy. London: Look Wood \& Son L/TD. Retrieved from https://archive.org/details/in.ernet.dli.2015.187264

Directorate General of Budget. (2019). Informasi Anggaran Pendapatan dan Belanja Negara 2019. (Direktur Penyusunan APBN, Ed.). Jakarta: Kementerian Keuangan Republik Indonesia. Retrieved from https://www.kemenkeu.go.id/media/11213/buku-informasi-apbn2019.pdf

Dluhosch, B., \& Zimmermann, K. W. (2006). Some Second Thoughts on Wagner's Law. Discussion Paper (Vol. 54). Hamburg, Germany. Retrieved from https://www.econstor.eu/obitstream/10419/23641/1/paper 54.pdf

García, M. J. (2018). Wagner's law: A Revision and a New Empirical Estimation. Revista Hacienda Pública Española / Review of Public Economics, 224(1), 13-35. from https://www.researchgate.net/publication/325545188 Wagner's law A Revision and a New Empirical Estimation

Granger, C. W. J., \& Newbold, P. (1974). Spurious Regression in Econometrics. Journal of Econometrics, 2(2), 111-120. Retrieved from https://doi.org/10.1016/0304-4076(74)90034-7

Gujarati, D. N., \& Poter, D. C. (2009). Basic Econometrics (5th ed.). Boston: McGraw-Hill.

Hasnul, A. G. (2016). The Effects of Government Expenditure on Economic Growth: the Case of Malaysia. Munich Personal RePEc Archive Paper, (71254). Retrieved from https://mpra.ub.uni-muenchen.de/71254/

Ighodaro, C. A. U., \& Oriakhi, D. E. (2010). Does The Relationship between Government Expenditure and Economic Growth Follow Wagner's Law in Nigeria? Annals of the University of Petrosani, Economics, 10(2), 185-198. Retrieved from https://www.upet.ro/annals/economics/pdf/2010/20100217.pdf

Ismal, R. (2011). Assessing Economic Growth and Fiscal Policy in Indonesia. East-West Journal of Economics and Business Journal, XIV(1), 53-71. Retrieved from https://www.u-picardie.fr/eastwest/fichiers/art94.pdf

Kurniawati, S. (2018). Granger Causality between Local Government Expenditure and Economic Growth in Indonesia. Journal of Business and Economics Review, 3(4), 80-86. Retrieved from https://ideas.repec.org/p/gtr/gatrjs/jber161.html

Kyaw, P. N. (2018). The Nexus between Economic Growth and Government Expenditure in Myanmar. Inya Economics Journal, 1(2), 2137. Retrieved from https://www.academia.edu/37427791/THE_NEXUS_BETWEEN_ECONOMIC_GROWTH_AND_GOVERNMENT_EXPENDITURE_I $\underline{\text { N_MYANMAR }}$

Law Number 26. (2007). Undang Undang Republik Indonesia Nomor 26 Tahun 2007, Tentang Penataan Ruang. Retrieved from https://walhi.or.id/wp-content/uploads/2018/07/UU-No-26-2007-ttg-Tata-Ruang.pdf

Magazzino, C., Giolli, L., \& Mele, M. (2015). Wagner's Law and Peacock and Wiseman's Displacement Effect in European Union Countries: A Panel Data Study. International Journal of Economics and Financial Issues, 5(3), 812-819. Retrieved from http://dergipark.gov.tr/download/article-file/363067

Manyeki, J. K., \& Kotosz, B. (2017). Empirical Analysis of the Wagner Hypothesis of Government Expenditure Growth in Kenya: ARDL Modelling Approach. Journal of Economic Literature (JEL), 13(2), 45-57. Retrieved from https://www.researchgate.net/publication/322875042_Empirical_Analysis_of_the_Wagner_Hypothesis_of_Government_Expenditure_Gro wth in Kenya ARDL Modelling Approach

Maurya, R., \& Sigh, B. P. (2017). Nexus of Economic Growth and Public Expenditure in India. Indian Journal of Economics and Development, 13(1), 165-170. https://doi.org/10.5958/2322-0430.2017.00022.1

Ministry of Public Works. (2014). Peningkatan Kapasitas Kelembagaan KSN Perkotaan Kedungsepur. Jakarta. Retrieved from https://www.scribd.com/presentation/249011256/Kelembagaan-KSN-Perkotaan-Kedungsepur 
INSIGHTS INTO REGIONAL DEVELOPMENT

ISSN 2669-0195 (online) http://jssidoi.org/ird/

2019 Volume 1 Number 2 (June)

http://doi.org/10.9770/ird.2019.1.2(2)

Mohammadi, H., \& Ram, R. (2015). Economic Development and Government Spending: An Exploration of Wagner's Hypothesis during Fifty Years of Growth in East Asia. Economies, 3(4), 150-160. Retrieved from https://www.google.com/url?sa=t\&rct=j\&q=\&esrc=s\&source=web\&cd=2\&ved=2ahUKEwjlmKqHworhAhVJknAKHfxDAjQQFjABegQI CRAC\&url=https\%3A\%2F\%2Fwww.mdpi.com\%2F2227-7099\%2F3\%2F4\%2F150\%2Fpdf\&usg=AOvVaw118ttdWc6slL1K5E8MOecy

Mutuku, C. M., \& Kimani, D. K. (2012). Investigating Wagner's Law-Cointegration and Causality Tests for Kenya. Current Research Journal of Economic Theory, 4(2), 43-52. https://www.researchgate.net/publication/256043889 Investigating Wagner's Law-Cointegration_and_Causality_Tests_for_Kenya

Neduziak, L. C. R., \& Correia, F. M. (2017). The Allocation of Government Spending and Economic Growth : A Panel Data Study of Brazilian States. Brazilian Journal of Public Administration, 51(4), 616-632. Retrieved from https://www.google.com/url?sa=t\&rct=j\&q=\&esrc=s\&source=web\&cd=1\&ved=2ahUKEwjVhJuf24PhAhXBNo8KHZ8gBW0QFjAAegQI DBAC\&url=http\%3A\%2F\%2Fwww.scielo.br\%2Fpdf\%2Frap\%2Fv51n4\%2Fen 1982-3134-rap-51-04-

00616.pdf\&usg=AOvVaw2SBNWT_mK9_iSNw-9M1Muf

Ogundipe, A. A., \& Oluwatobi, S. (2013). Governement Spending and Economic Growth in Nigeria: Evidence from Disaggregated Analysis. Journal of Business Management and Applied Economics, 2(4), 1-10. Retrieved from https://www.researchgate.net/publication/307122666_Government_Spending_and_Economic_Growth_in_Nigeria_Evidence_from_Disagg regated Analysis

Okoro, A. S. (2013). Government Spending and Economic Growth in Nigeria (1980-2011). Global Journal of Management and Business Research Economics and Commerce, 13(5), 21-29. Retrieved from https://globaljournals.org/GJMBR Volume13/4-GovernmentSpending-and-Economic.pdf

Presidential Regulation of the Republic of Indonesia. (2017). Peraturan Presiden Republik Indonesia Nomor 78 Tahun 2017, Tentang Rencana Tata Ruang Kawasan Perkotaan Kendal, Demak, Ungaran, Salatiga, Semarang, dan Purwodadi. Retrieved from https://www.google.com/url?sa=t\&rct=j\&q=\&esrc=s\&source=web\&cd=1\&ved=2ahUKEwjLirowYrhAhUKKo8KHXdvDAAQFjAAegQIAxAC\&url=http\%3A\%2F\%2Fsipuu.setkab.go.id\%2Fpuu\%2Fbuka_puu\%2F175325\%2FPerpr es\%2520Nomor\%252078\%2520Tahun\%25202017.pdf\&usg=AOvVaw3ajdTy28FheV9t3b6oh

Rosadi, D. (2012). Ekonometrika dan Analisis Runtun Waktu Terapan Dengan Eviews. Yogyakarta: ANDI.

Skousen, M. (2006). Sang Maestro “Teori-Teori Ekonomi Modern”: Sejarang Pemikiran Ekonomi. Jakarta: Prenada Media.

Uddin, M. M., \& Aziz, M. S. I. (2015). Effect of Public Investment on Economic Growth in Bangladesh: An Economitric Analysis. Journal of Economics and Sustainable Development, 5(22), $37-50 . \quad$ Retrieved https://pdfs.semanticscholar.org/7f84/c9c0b12762cb7da8400e8af88f23fcfe578e.pdf

Uzuner, G., Bekun, F. V, \& Akadiri, S. S. (2017). Public Expenditures and Economic Growth: Was Wagner Right? Evidence from Turkey. Academic Journal of Economic Studies, 3(2), $436-40 . \quad$ Retrieved https://www.researchgate.net/publication/316167276_Public_Expenditures_and_Economic_Growth_Was_Wagner_Right_Evidence_from_ $\underline{\text { Turke }}$

Wang, L., Peculea, A. D., \& Xu, H. (2016). The Relationship between Public Expenditure and Economic Growth in Romania: Does it Obey Wagner's or Keynes's Law? Theoretical and Applied Economics, XXIII(3608), 41-52. Retrieved from https://www.google.com/url?sa=t\&rct=j\&q=\&esrc=s\&source=web\&cd=1\&ved=2ahUKEwippK7eworhAhWLQY8KHVPjAcwQFjAAegQ IABAC\&url=http\%3A\%2F\%2Fstore.ectap.ro\%2Farticole\%2F1197.pdf\&usg=AOvVaw0W8E0FfM0usRowXuHQyT7k

Winarno, W. W. (2015). Analisis Ekonometrika dan Statistika dengan Eviews (4th ed.). Yogyakarta: UPP STIM YKPN 
INSIGHTS INTO REGIONAL DEVELOPMENT

ISSN 2669-0195 (online) http://jssidoi.org/ird/

2019 Volume 1 Number 2 (June)

http://doi.org/10.9770/ird.2019.1.2(2)

Gatot SASONGKO, Dr. is an associated professor and the head of economics department at the Faculty of Economics and Business of Satya Wacana Christian University. His fields of expertise are labor economics, quantative research and macroeconomic policy. His publications have appeared at various national journals in Indonesia and international journals.

ORCID ID: https://orcid.org/0000-0003-0381-9348

Andrian Dolfriandra HURUTA, M.Si. is a lecturer at the Faculty of Economics and Business of Satya Wacana Christian University. His fields of expertise are macroeconomic policy and applied econometrics. His publications have appeared at various national journals in Indonesia and international journals.

ORCID ID: https://orcid.org/0000-0001-7676-5294

Anita WARDANI. is an undergraduate at the Faculty of Economics and Business of Satya Wacana Christian University. Her fields of expertise are macroeconomic policy and applied econometrics.

ORCID ID: https://orcid.org/0000-0003-1732-9753

Copyright (C) 2019 by author(s) and VsI Entrepreneurship and Sustainability Center

This work is licensed under the Creative Commons Attribution International License (CC BY).

http://creativecommons.org/licenses/by/4.0/

CC) (i) Open Access 